地震 2 輯

第 42 巻 (1989) 325-331 頁

\title{
深さが負にならない震源決定
}

\author{
東京大学地震研究所* 纈 纈 一 起
}

\section{Hypocenter Determination with Non-negative Depth}

\author{
Kazuki KoKetsu \\ Earthquake Research Institute, University of Tokyo, Yayoi 1-1-1, Bunkyo-ku, Tokyo 113, Japan \\ (Received July 14, 1989; Accepted August 22, 1989)
}

\begin{abstract}
Some techniques used in statistics, such as the variable change method, the penalty function method and the gradient projection method, are introduced to determine the location of a hypocenter with a definitely non-negative depth. Numerical simulations are carried out to compare the efficiency of them by using synthetic arrival time data for a four-station seismic array. They demonstrate that the penalty function method with a proper weight is the most efficient. However, if we take an improper weight, it may lead to a negative depth or an invalid solution. Since the variable change method and the gradient projection method do not have such arbitrariness, those can be implemented more easily into hypocenter determination processes operated routinely. The demonstration with real arrival time data shows that the variable change method as $z=h^{2}$ has practical efficiency.
\end{abstract}

\section{§1。はじめに}

震源決定は地震学分野のもっとも古典的な数値計算で ある. そのため, HYPO71 [LEE and LAHR (1972)] や HYPOINVERSE [KLEIN (1978)] などの標準プログラム が広く受け入れられている現状では, 震源決定の数値計 算としての手法はほぼ確立した段階にあると言えるだろ う.たとえば最近の統計学の常識によれば [中川・小柳 (1982), LAwson and HANSON (1974) などの教科書を参 照], 最小自乗問題の安定化のためには束縛条件 (拘束条 件）を付加するのが理にかない, 性能む良いということ になっており, 地震学分野への適用も試みられている [JACKSON (1979), Tarantola and ValetTE (1982)な ぞ]. しかし筆者の経験では, 他の方法で信頼性の高い推 定值が得られているような場合を除いて，これら標準プ ログラムが採用している修正べクトルの縮小が, 束縛条 件の付加に比へ性能的に劣るということはなかった．重 要なのは, 束縛条件がベクトル縮小かという二者択一で はなく, 束縛の強さあるいは縮小の大きさを適切に選へ るかである. 束縛の場合には, どういう形の束䋠条件を 選ぶかも大きな問題である.

最近 LIENERT et al. (1986) は, 観測方程式のセンタリ ング,スケーリングを伴った Adaptively Damped

* 7113 東京都文京区弥生 1-1-1
Least Squares 法による彼らのプログラムHYPOCENTER が, 深さの推定において HYPO71 や HYPOINV ERSE より優れていると述へている. Damped Least Squares 法はよく知られるように, 「解は初期值から大 きく離れない」という束縛条件を与えた最小自乗法で, 3 次元構造の推定に広く用いられている [AKI ana LEE (1976)など]. Adaptively とは, その場合の束縛の強さ を走時残差に応じて変化させることを意味する．しかし 筆者の実験によれば, HYPO71, HYPOINVERSE が深 さ決定に良い結果を与えていないのは，LIENERT etal. (1986) が用いているような構造を既知とするシミュ レーションでは，それらが深さをフリーにする条件が厳 しすぎるためである。 そのため HYPO71, HYPOINVERSE は簡単に深さを固定してしまい, 正しい解を与え ない. 実データによる実験についても同様なことが言 え,このことは LIENERT et al. (1986) の図面から明らか に読み取れる。

それでは束縛の強さ/ベクトル縮小の大きさの選択を 除いて, 震源決定アルゴリズムのすべてが解決済みであ ろうか. Table 1 は LIENERT et al. (1986) の TABLE 1 を元に, HYPO71, HYPOINVERSE 及び HYPOCENTER のアルゴリズムを比較したものである．これを見 ると「負の深さ」の取り扱いについて, 今まで深い考察 がされていないことに気づく. どのアルゴリズムも, 深 
Table 1. Comparison of the algorithms of HYPO71, HYPOINVERSE and HYPOCENTER.

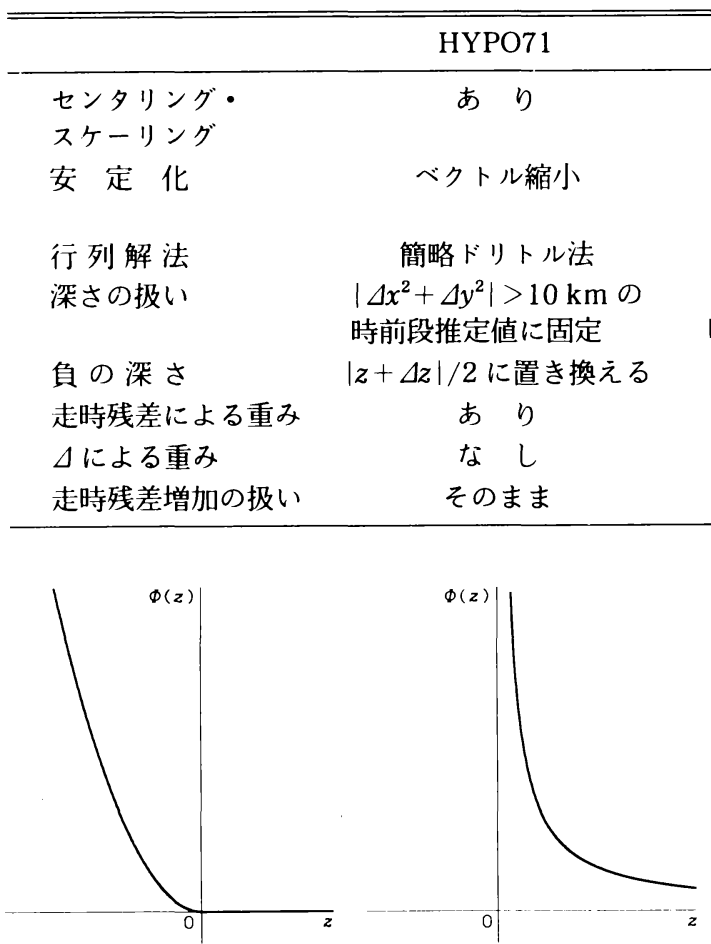

Fig. 1. An external penalty function (left) and an internal penalty function (right).

さが負になったらある値に置き換えるような対症療法し か行なっていない，そこで本論文では，定式化本来の性 質から深さが負にならないようにする震源決定のアルゴ リズムについて考える.

\section{2. 非負のための手法}

震源決定に限らず，不等式の制約条件を満たしながら 非線型最小自乗を実現する手法は, 次の 3 つが考えられ る.
(1) 変数変換法
(2) ペナルティ関数法
(3) 勾配射影法

\section{1. 変数変換法}

震源の深さ $z$ が $z \geq 0$ を満たさなければならないなら, $z$ をその制約条件を満たす関数形，たとえば $z=|w|, h^{2}$ あるいは $e^{d}$

に置き換えてしまうのが变数変換法である. 方法として 非常に明解でわかりやすく, 従来の震源決定プログラム からの変更もやさしい. 理論走時を $T$ とすると, $T$ の助 変数に関する偏微分係数は

\section{HYPOCENTER}

なし あり

ベクトル縮小

$\mathrm{QR}$ 分解法 $\left|\Delta x^{2}+\Delta y^{2}\right| \geq 7 \mathrm{~km}$ の 時前段推定値に固定

Adaptively Damped Least Squares 特異值分解法

走時残差が操り返し增加する 時前段推定值に固定 $z / 2$ に置き換える あり あり 前段推定値に戻り束縛を強くする な なし 前段推定値に戻る 前段推定值に戻り束縛を強くする

$$
\begin{aligned}
& \frac{\partial T}{\partial w}=\frac{\partial T}{\partial z} \cdot \frac{w}{|w|}, \frac{\partial T}{\partial h}=\frac{\partial T}{\partial z} \cdot 2 h \\
& \text { あるいは } \frac{\partial T}{\partial h}=\frac{\partial T}{\partial z} \cdot z
\end{aligned}
$$

とするだけで計算できる. 欠点は, (1) 式からわかるよう に問題の非線型性が強くなり, 不安定になりやすいこと である．そのため安定化を強くはかる必要がある.

\section{2. ペナルティ関数法}

ペナルティ関数とは, 最適化問題の変数に与えられる 制約を, 束縛条件の形に変形したものである. ペナル ティ関数には外点ペナルティと内点ペナルティの 2 種 類がある [今野・山下 (1978)]．たとえば $z \geq 0$ を実現し たいなら

$$
\begin{aligned}
\Phi(z) & =|z|^{\alpha} & & z<0 \\
& =0 & & z \geq 0
\end{aligned}
$$

が外点ペナルティ関数であり， $\alpha \geq 1$ とする.この関数は Fig. 1 左側の形をしているので, $z$ が 0 より小さくなる ほど值が大きくなる，そこで震源決定において，単なる 走時残差の自乗和

$$
S_{o}=\sum_{i}\left(t_{i}-T_{i}(x, y, z)-t_{o}\right)^{2}
$$

を最小にするのではなく， $\Phi(z)$ を付け加えて

$$
S=S_{o}+\lambda \Phi(z)
$$

を最小にするよう変形する．ここで $(x, y, z)$ と $t_{0}$ は震源 座標と震源時, $t_{i}$ と $T_{i}$ は $i$ 番目の観測点における観測 走時と理論走時である. また入はペナルティ関数の重み を表わす． $\Phi(z)$ は $z<0$ では大きな值を取るので，適切 な入のもとで $S$ が正しく最小化されれば， $z<0$ にはな らないはずである.

一方, 制約 $z \geq 0$ に対する内点ペナルティ関数は

$\Phi(z)=1 / z^{\beta} \quad z>0$

と定義され， $\beta>0$ とする.これは Fig. 1 右側の形を取 
り, $z$ が正の領域から 0 に近づくにつれ大きくなる. 従って外点ぺナルティ関数と同様, (5) を最小化すれば $z$ は 0 以下にはならないはずである.

外点ペナルティ関数 (3) に比べると, (6) の方が能率が

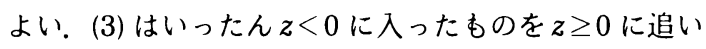
込む形になるのに対し，(6) は $z=0$ で無限大に発散する ので， $z \geq 0$ から始めれば， $z<0$ に入り込む危険性は少 ない，領域内初期值が得られない場合, 内点ペナルティ 関数は利用できないが, 震源決定では $z_{o}>0$ と置くだけ でよいので問題にはならない。

ペナルティ関数法は適切な重み入を選択できれば, 安 定で収束もよい，また $z \geq 0$ といった単純なあのだけで なく、より複数な制約にも適用でき拡張性も高い。しか し適切な入は最適化問題の形式, デー夕の品質などで異 なり，普遍的な導出方法がない，大きすぎれば正しい解 に到達せず，小さすぎれば制約が実現できない，今野・ 山下 (1978) にすれば，まず大きな入で最適化を行ない. 次にその解を初期値にして少し小さな $\lambda$ で最適化を行 うということをくり返せば，正しい解に収束するとい う. しかし震源決定のイタレーションの外側に, さらに 入のイタレーションを設けるというのはあまりに染長で 現実的ではないだろう.

\section{3. 公配射影法}

変数変換法やペナルティ関数法に比へ，勾配射影法は 比較的単純である。 たとえば, 震源決定のあるステップ の初期値が $z$ の正領域にあったのに (Fig. 2 点 A), 計算 結果の修正ベクトルを適用すると負領域に飛び出してし まう場合 (B), 修正べクトルの正領域部分 (AC) 上でもっ とも $S_{o}[(4)$ 式] を小さくする点 (D) を解とする. また, このような操作により初期值が $z=0$ となり $\left(\mathrm{A}^{\prime}\right)$, さら に修正べクトルを適用した解も $z \leq 0$ となった時 (B'),

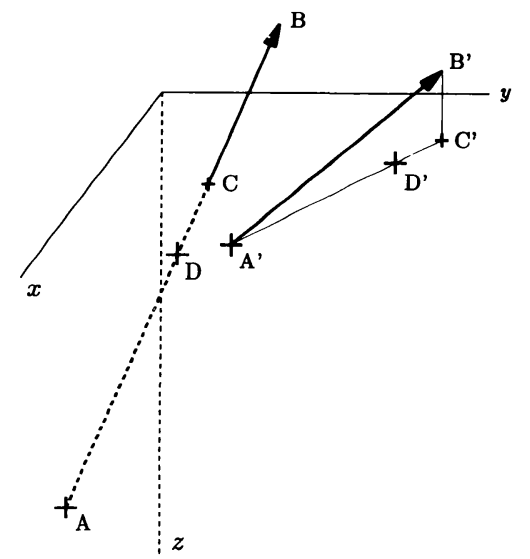

Fig. 2. Operations of the gradient projection method.
ベクトル全体 $\left(\mathrm{A}^{\prime} \mathrm{B}^{\prime}\right)$ が負領域に入ってしまう。この場合 はベクトルを $z=0$ 平面に投影し，投影べクトル $\left(\mathrm{A}^{\prime} \mathrm{C}^{\prime}\right)$ 上で $S_{o}$ を最小にする点 $\left(\mathrm{D}^{\prime}\right)$ をこのステップの解とす る.

今野・山下 (1978) は, こうした手続きである解に達 した時，それは制約下の最適解のひとつであることを証 明している. しかし, 震源決定においては理論走時を計 算して $S_{o}$ を求める部分がもっとも時間がかかるので, $\mathrm{AC}$ または $\mathrm{A}^{\prime} \mathrm{C}^{\prime}$ 上で $S_{o}$ 最小の点を挆す [このような操 作を直線探索 (Line Search) という] ため， $S_{o}$ をくり返 し計算することは現実的でない，そこで以下では，C あ るいは $\mathrm{C}^{\prime}$ を解とする方法を勾配射影法と呼ぶことにす る.

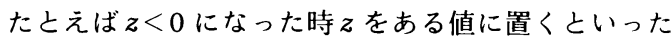
簡略法に比へ, 勾配射影法の特徴は, 得られた修正べク トルの情報をなるべく生かそうとする点にある. 生かす ことにより，イタレーションが本来の収束経路から大き くはずれておかしな解に達したり，収束が著しく遅くな るなどの障害を回避することを意図している。しかし $\mathrm{A}^{\prime} \mathrm{B}^{\prime}$ のような場合に経路からはずれてしまうのはよ゙う しょうもないので, 収束が悪くなったり不安定になりや すいのがこの方法の欠点である.

なお, $z<0$ から以後 $z$ を固定して変数としない操作か よく行なわれるが，この方法において適当な条件で $z$ を 復活させるのが LAwson and HANSON (1974)の Nonnegative Least Squares である [MENKE (1984)の § 7.9 も同様]. Algebraic Reconstruction Technique に おける “trick” [HERMAN (1980)] は, 簡略法の一種とい える.

\section{3. シミュレーション}

2 節で述べた 3 手法を比較するため, パソコン (PC$9801 \mathrm{VX)}$ 上で MS-FORTRAN Version 4.01 を用いて シミュレーションを行った．負の深さの扱い以外のアル ゴリズムはなるべく HYPOCENTER のもの (Table 1) に従ったが，明らかに優れているものが他にある場合は それを採用した (Table 2)。つまり，斎藤 (1983)など多 くの人が指適しているように, 最小自乗法の行列解法は 観測行列の係数行列在 QR 分解する方法が数值的に安定 であり, 特異値分解法により計算時間も短い. 大きめの ダンピング係数から始めれば係数行例が特異になること あないので，QR 分解法を用いることにする．また事前 のテストでは, QR 分解法を用いる場合スケーリングの 効果はほとんどなかったので，スケーリングは行なわず センタリングのみ行なった。 センタリングとは，観測方 程式に震源時 $t_{o}$ が一次の形でしか含まれないのを利用 
Table 2. Features of the algorithm used in simulations.

\begin{tabular}{|c|c|}
\hline $\begin{array}{l}\text { センタリング・ } \\
\text { スケーリング }\end{array}$ & センタリングのみ \\
\hline 安 定 化 & $\begin{array}{l}\text { Adaptively Damped Least } \\
\text { Squares }\end{array}$ \\
\hline 行列解 法 & QR 分解法 \\
\hline 深さの扱い & 常に自由 \\
\hline 負 の 深 さ & $\S 2$ の手法を適用 \\
\hline 走時残差による重み & な し \\
\hline$\Delta$ によよる重み & な し \\
\hline 走時残差增加の扱い & $\begin{array}{l}\text { 前段推定値に戻り束縛を強く } \\
\text { する }\end{array}$ \\
\hline
\end{tabular}

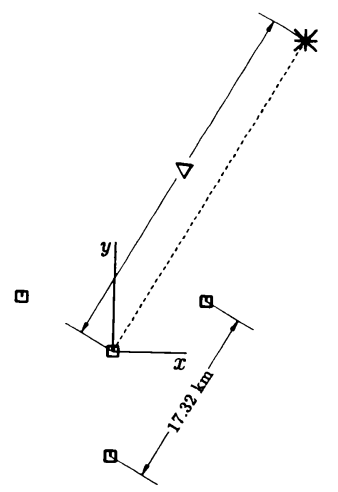

Fig. 3. Configuration of an epicenter and stations for the simulation.

して，正規方程式を $t_{o}$ について explicit に解いてしま い，見かけ上変数が $x, y, z$ だけにする手法である [DRAPER and SMITH (1966)]. 震源時と深さの trade-off をみかけ上解消するために，もっとも簡便で有効な手法 と思われる.さうに，深さの扱いでは 3 手法の違いを明 確にするため, 深さ固定などの操作を一切行なわなかっ た.

観測点配值は LIENERT et al. (1986) の NET1 arrray を採用した．Fig. 3 に示したように，これは正三角形の 各頂点および重心に観測点を置いたものである．震源 (*) は重心より右上 $60^{\circ}$ の方向, $\Delta=50 \mathrm{~km}, z=25 \mathrm{~km}$ に ある. 2 層構造を考え, 厚さ $30 \mathrm{~km}$ の上首の $\mathrm{P}$ 波速度を $6 \mathrm{~km} / \mathrm{s}$, 下層では $8 \mathrm{~km} / \mathrm{s}, \mathrm{V}_{\mathrm{P}} / \mathrm{V}_{\mathrm{s}}$ はともに 1.78 とす る. $\mathrm{P}$ 波および $\mathrm{S}$ 波の観測走時は, 理論走時にそれぞれ 標隼偏差 0.05 秒および 0.1 秒の正規乱数を与えて作っ た。 また震源決定の初期値は，もっとも走時の早い観測 点（右上頂点）から $x, y$ とも $0.1 \mathrm{~km}$ ずれた位置の, 深 さ $15 \mathrm{~km}$ に置いた。 ダンピング係数はやはり HYPOCENTER と同じく, 初めて 0.005 とし走時残差が大きく

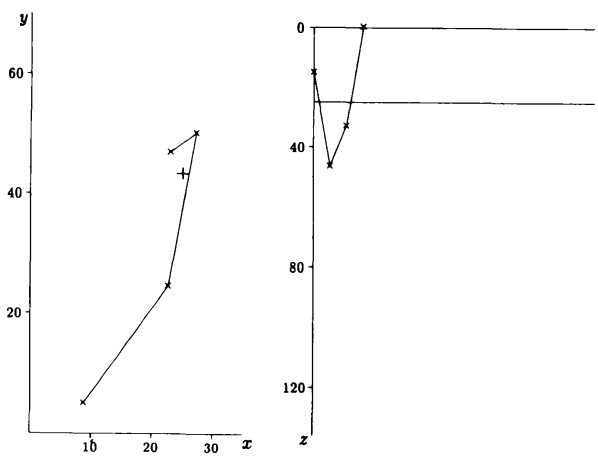

Fig. 4. The progression of simulation through the hypocenter determination process without remedy for negative depth.

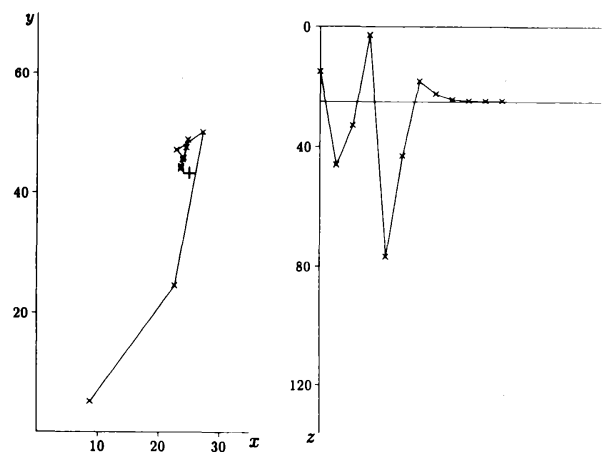

Fig. 5. The progression of simulation through the hypocenter determination process with the variable change as $z=|w|$.

なれば 4 倍，小さくなれば 0.6 倍することとした.

Fig. 4 は，負の深さの対策を何もしなかった場合のイ タレーションの経過を示したものである. 左側はステッ プごとの震源の水平位置を, 重心観測点を原点とする $x$, $y$ 座標 (Fig. 3) で表わしてプロットしてある. また右側 はステップごとの震源深さ $z$ である. 3 ステップ目で $z$ $=-2.8 \mathrm{~km}$ となり, 計算の続行が不可能となる.

そこで変数变換法を適用し, $z=|w|$ と変換した場合が Fig. 5 である.ここでは順調に正しい解に達している. ただし深さの収束はあまり速くなく，かなり暴れてい る. さらに $z=h^{2}$ 之置換すると Fig. 6 となる. Fig. 5 に 比べる水平位置は多少回り道しているが，深さの暴れ 万は少ない. 最後に $z=e^{d}$ の置換を行なうと Fig. 7 の通 りになる. $|w| や h^{2}$ に比べて $e^{d}$ の非線型性が強いので, 第 1 ステップでひどくはずれた解になってしまい，収束 あ非常に遅くなっているが, 正解には達している.

Fig. 8 から Fig. 10 は, ペナルティ関数法のイタレー ション経過である．ペナルティ関数は内点ペナルティ関 数 $1 / z$ をとった. ペナルティの重み $\lambda[(5)$ 式］を 2 とし 


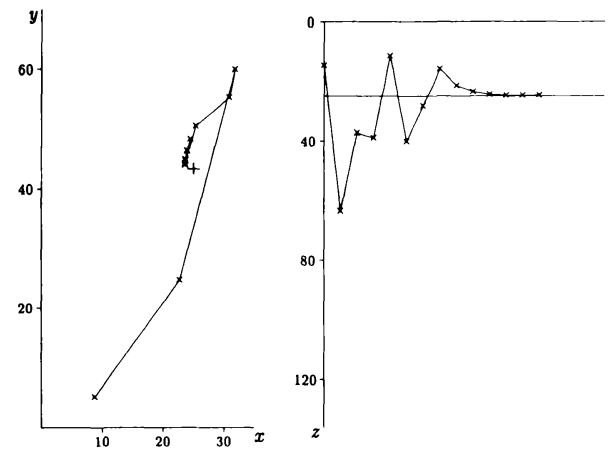

Fig. 6. The progression of simulation through the hypocenter determination process with the variable change as $z=h^{2}$.
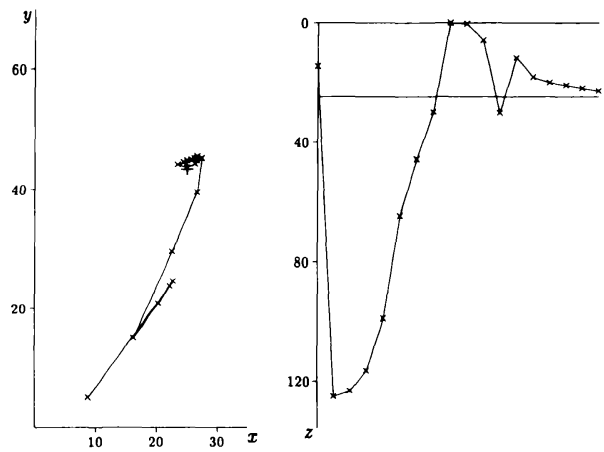

Fig. 7. The progression of simulation through the hypocenter determination process with the variable change as $z=e^{d}$.

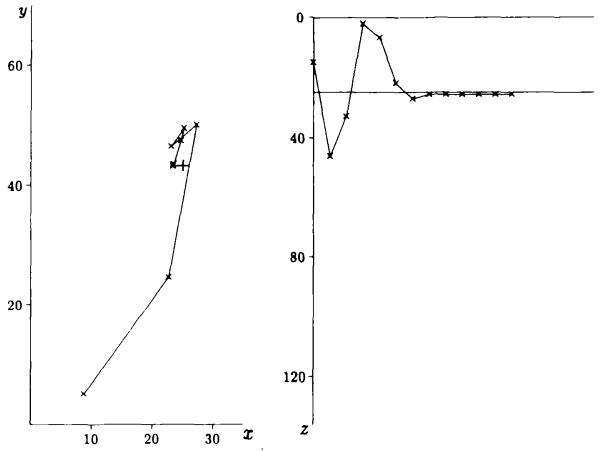

Fig. 8. The progression of simulation through the hypocenter determination process with the internal penalty function $1 / z$ and $\lambda=2$.

たFig. 8 では，正解に達しているだけではなく収束も速 い.ところが $\lambda=1$ とした Fig. 9 では Fig. 4 とほとんど 同じ経過をたどり，第 3 ステップで $z=-0.3 \mathrm{~km}$ となっ た計算の続行が不可能となった。 また $\lambda=100$ とすると

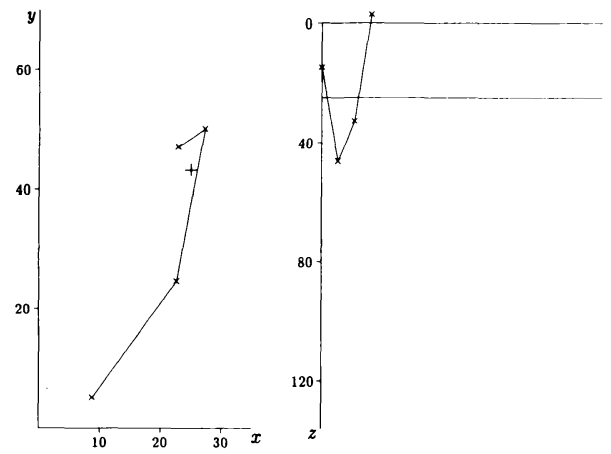

Fig. 9. The progression of simulation through the hypocenter determination process with the internal penalty function $1 / z$ and $\lambda=1$.

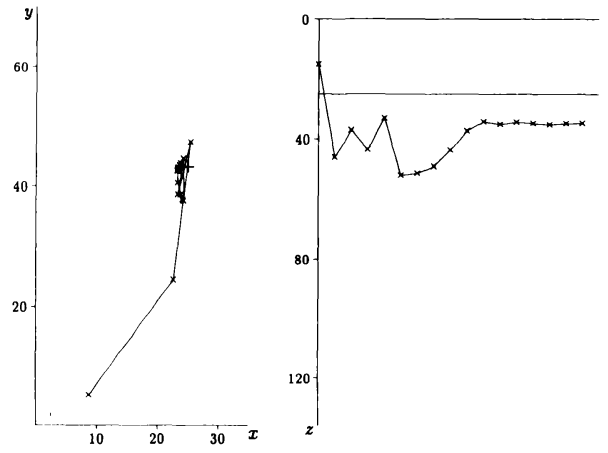

Fig. 10. The progression of simulation through the hypocenter determination process with the internal penalty function $1 / z$ and $\lambda=$ 100.
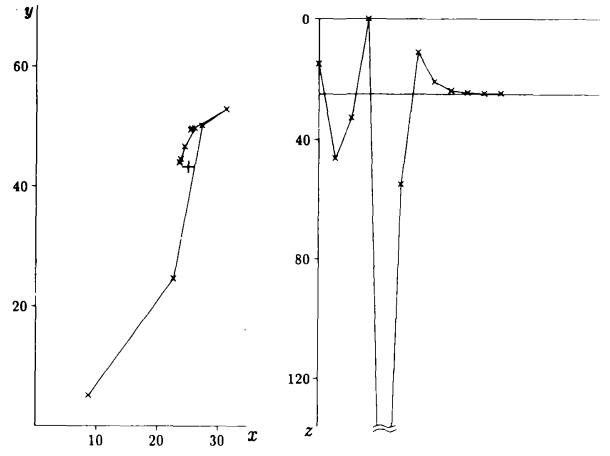

Fig. 11. The progression of simulation through the hypocenter determination process with the gradient projection method.

(Fig. 10) 収束状況は非常に落ち着いたものになるが， $z$ $=40 \mathrm{~km}$ 付近で水平位置が振動してしまい正解には達 しなかった.このように，シミュレーションでも，適切 な重みが選択できれば安定で収束が速いが，重みが大き 
すぎれば正しい解に達せず，小さすぎれば制約が実現で きないという，ペナルティ関数法の欠点がはっきり現わ れた。

最後に勾配射影法のシミュレーションを Fig. 11 に示 す. 第 3 ステップで $z<0$ となり， $z=0$ となる点で修正 ベクトルを切断した。この切断によりイタレーションは 収束経路をはずしてしまい，次のステップはひどく不安 定で, $z=221 \mathrm{~km}$ という深さに求まってしまっている。 しかし，その後は順調に正解に達している.

\section{4、ルーチン処理への適用}

前節のシミュレーションから 3 手法の優劣，特にルー チン処理などの実際的な現場での処理に適用した場合の 優劣を考えてみる。 そうした場合には計算時間がかかり 過ぎる，手順が複雑過ぎるということは避けなければな らないだろう。

シミュレーションの結果の中で，むっとも安定でしか も収束が速かったのは， $\lambda=2$ の時のペナルティ関数法 である.しかし入が 2 という最適值でなかった場合， $z$ $\geq 0$ が実現できなかったり正解に達しなかった． 2 とい う入の最適値は前節のシミュレーションに限られるも のであり, 用いる構造, 震源の位值, 観測点の配置, 読 み取りの品質などで異なってしまう性質のものである. ある程度のデータが畜積されていれば，それを用いて震 源の位置や観測点の組み合せに対する最適 $\lambda$ を調べつ くすことは可能であるが，かなりの作業となることが予 想される。

一方，変数变換法と勾配射影法はペナルティ関数法ほ どの性能を持たないが，こうした任意性がないので特別 な準備なしに適用することができる，またどちらあ，そ のために必要な計算時間はほんのわずかである．両者の シミュレーション結果を比べてみると, $z=|w|$ あるいは

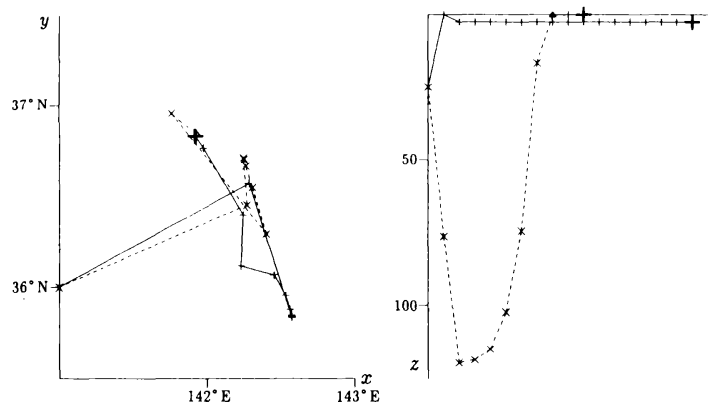

Fig. 12. The progression of hypocenter location for real travel time data through the hypocenter determination process with the varialble change as $z=h^{2}$. $h^{2}$ とする変数変換法がもっとも安定な収束状況を示し た. しかし，常にこれがあっとも安定であるとは限らな い. 関数形から見て, $z=e^{d}$ より $z=|w|$ や $h^{2}$ の方が非 線型性が小さく優れていると考えられるが，現実のデー 夕によるテストでは，変数变換法自体之勾配射影法之の 優劣はつけがたかった。ただ勾配射影法には，何回射影 しても $z$ が負になってしまう可能性も残されているが, 変数变換法は確実に $z \geq 0$ としてくれる. また勾配射影 法は, 負の深さの扱いとして従来用いられてきた方法と よく似かよっているのに比へ，变数变換法はこれまで用 いられることが少なかったので，その意味で試してみる 価値があると考えられる。

地震予知観測情報ネットワークにおけるリアルタイム 地震デー夕の統合処理 [纐縝・他 (1989)] には, $z=h^{2}$ の 変数変換法を探用した. Fig. 12 は, その処理プログラム を 1987 年 3 月 10 日の福島県沖の地震 （気象庁マグニ チュード 5.6) に適用した例である．Fig. 13 の観測点に おける $\mathrm{P}$ 波の自動処理読み取りを用いて震源決定を 行った. 自動処理は東北大学理学部地震予知 ・噴火予知 センターのシステム [長谷川・他 (1986)] によるもので ある. 初期值は $36^{\circ} \mathrm{N}, 141^{\circ} \mathrm{E}$, 深さ $25 \mathrm{~km}$ とした. 福島 県沖はもともと深さが負になりやすい地域であるが, ネットワークの状況により Fig. 13 のように観測点が北 に片寄った場合には, 特にその傾向が強い. Fig. 12 で実 線は初めから $z=h^{2}$ 之おいた場合で，点線は変数変換な しで始めて, 深さが負になった段階（図中の $\triangle$ ) で $z=h^{2}$

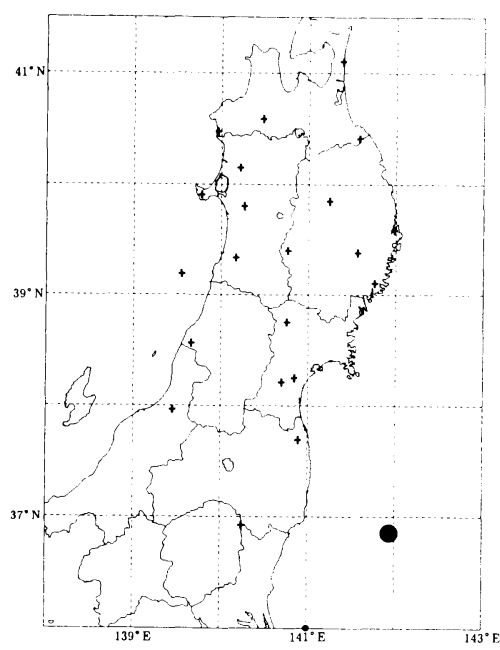

Fig. 13. Map of the university stations where the March 10, 1987 earthquake $\left(M_{\mathrm{JMA}}=5.6\right)$ was observed. Small and large circles indicate the initial guess and the final solution of its epicenter. 
之置換する場合の収束状況を示している，前者では $z$ が 比䡆的安定であるが, 水平位置は少々暴れており, 後者 はその逆の傾向を見せている. 両者とも最終的にはほぼ 同じ位置に収束するが，後者の方がやや収束が速い。

\section{5。結論}

深さを負にしないで震源決定する方法として, 統計学 などで用いられている変数变換法, ペナルティ関数法, 勾配射影法を導入し，その優劣をシミュレーションで検 討した. シミュレーションでは深さの取り扱いを除いて 基本的に LIENERT et al. (1986) のアルゴリズムを採用し て同一条件とし, 観測点配置などは LIENERT et al. (1986)が用いたものをそのまま採用した，特別な対策を 施さないで震源決定をした時, 深さが負になってしまう ような震源に対してシミュレーションを行った結果, 適 切な重みを与える場合のペナルティ関数法がもっとも安 定で収束が速かった。しかし重みが適切でなかった場 合, ペナルティ関数法では $z \geq 0$ が実現できなかったり 正解に達しないということが起こった。 ルーチンの震源 決定ではこうした任意性はできるだけ避けたいので, 変 数変換法や勾配射影法の方が導入しやすい.これらの中 では $z=|w|$ あるいは $h^{2}$ とおく変数変㬇法があっとも安 定であった。後者を実際のデー夕に適用した場合でも良 い結果を得た。

負の深さというのは，用いた構造，観測点配置，読み 取り精度などが適切でないことを示すから， $z=0$ など とおいて，そうなったことを明示した方がよいという考 え方もある. しかしそうした場合でも， $z \geq 0$ という物理 的条件を満たした上で走時残差の自乗和を極小とする解 は，情報として意味があると筆者は考えている.

最後にここで述へた 3 手法とも, 震源決定に限らず, 最小自乗法を用いるすべての最適化問題に適用可能であ ることを調強しておきたい，YoshidA (1988) は震源過 程の波形インバージョンにおいて，〈い違い量を非負と するため $\beta=1$ の内点ぺナルティ関数法を用いている.

\section{謝辞}

吉田真吾博士（東京学芸大）には変数変換法に関し, 重要な指摘をいただきました。また尾形良彦博士（統数 研）之宮武隆博士（東大地震研）にはいろいろご教授い ただきました. Fig. 12 及び Fig. 13 の例では, 東北大学 地震予知・噴火予知センターの自動処理結果を利用させ ていただき，長谷川昭教授を初めとする同センターのス
タッフの方々に感謝致します。

\section{文献}

AKI, K. and W.H.K. LEE, 1976, Determination of three-dimensional velocity anomalies under a seismic array using first $P$ arrive times from local earthquakes. 1. A homogeneous initial model, J. Geophys. Res., 81, 4381-4399.

Draper, N. R. and H. Smith, 1966, Applied Regression Analysis, John Wiley \& Sons, New York (中村慶一 (訳), 1968, 応用回帰分析, 森北出版, 378pp.).

長谷川昭・海野徳仁・山本 明・高木章雄, 1986, 微小 地震観測網データの自動処理システム, 地震 $2, \mathbf{3 9}$, 381-395.

Herman, G. T., 1980, Image Reconstruction from Projections, Academic Press, New York, 316pp.

JACKson, D. D., 1979, The use of a priori data to resolve nonuniqueness in linear inversion, Geophys. J. R. astr, Soc., 57, 137-157.

KLeIN, R. W., 1978, Hypocenter Location Program HYPOINERSE Part I: Users Guide to Versions 1, 2, 3 and 4, U. S. Geol. Surv. Open-File Rept. 78-694.

䋶䋶一起・鷹野 澄・坪井誠司・宮武 隆・阿部勝征・ 荻原幸男, 1989, 地震予知観測情報ネットワークにお けるリアルタイム地震データの統合処理, 地震研究所 彙報, 投稿中.

今野 浩・山下 浩, 1978, 非線型計画法, 日科技連出 版社, $354 \mathrm{pp}$.

Lawson, C. L. and R. J. Hanson, 1974, Solving Least Squares Problems, Prentice-Hell, Englewood Cliffs. $340 \mathrm{pp}$.

LeE, W. H. K. and J. C. LAHr, 1972, HYPO71: A compututer program for determining hy pocenter, mag. nitude, and first motion pattern of local earthquakes, U. S. Geol. Surv. Open-File Rept. 75-311.

LIENERT, B. R., E. BERG and L. N. FrAZER, 1986, HYPOCENTER: An earthquake location method using centered, scaled, and adaptively damped least squares, Bull. Seismol. Soc. Am., 76, 771-783.

Menke, W., 1984, Geophysical data analysis: Discrete inverse theory, Academic Press, New York.

中川 徹・小柳義夫, 1982 , 最小二乗法による実験デー 夕解析, 東京大学出版会, $206 \mathrm{pp}$.

斎藤正徳, 1983, 最小二乗法の計算法, 物理探鉱, $\mathbf{3 6}$, No. 2, 24-38.

Tarantola, A. and B. Valette, 1982, Generalized nonlinear inverse problems solved using the leastsquares criterion, Rev. Geophys. Space Phys., 20, 219-232.

Yoshida, S. 1988, WAVEForm inversion for rupture processes of two deep earthquakes in the Izu-Bonin region, Phys. Earth Planet. Inter., 52, 85-101. 